\title{
Change or Decay? An interpretation of late Holocene archaeological evidence from the Hamersley Plateau, Western Australia
}

\author{
BEN MARWICK
}

Keywords: Pilbara, Holocene, chronology, cultural change

\begin{abstract}
Data collected from the Hamersley Plateau over the last four decades are examined for patterns in the archaeological record. Data relating to the timing of the archaeological appearance of backed artefacts, seed-grinding technology and rock art are currently too few to indicate major cultural changes with certainty. Increases in numbers of radiocarbon dates from archaeological sites on the Hamersley Plateau are evident in the late Holocene. This can be interpreted as a pattern of cultural change or natural decay in datable material. I conclude that taphonomic bias is the most important variable in the distribution of the radiocarbon date sample from the Hamersley Plateau. That said, further accumulation of dates and data may show archaeological changes in the Hamersley Plateau that represent local expressions of broader trends in the Australian semi-arid and arid zones.

Studies of regional archaeology in Australia often describe a late Holocene (i.e. after $4000 \mathrm{BP}$ ) phenomenon of increases in the diversity and quantity of archaeological evidence (e.g. David and Chant 1995, Flood et al. 1987, Lourandos 1983, Morwood 1987). Despite the abundance of archaeological resources in the Hamersley Plateau, it is one of the few regions of the Australian continent that has been excluded from discussions of late Holocene change (Figure 1). This is mostly because data from the area are hidden in a grey literature of consultant reports that has accumulated over the last four decades. This aim of this paper is to evaluate the implications of evidence on the dating of backed artefacts, seed grinding technology, rock art and fluctuations in occupation intensity on the Hamersley Plateau.
\end{abstract}

\section{The dating of backed artefacts and adzes}

Backed artefacts and adzes have long been a focus of debates about cultural and technological change in Australian archaeology (Bowdler 1981; Bowdler and O'Connor 1991; Hiscock 2001; 2002; Hiscock and Attenbrow 1998; 2004; Layton 1996). The first evidence of these new types on the Hamersley Plateau is a backed stone artefact with resin on the backed section at Newman Rockshelter. The artefact is associated with a date of

Department of Anthropology, University of Washington, Seattle, WA, 98195-3100, USA. bmarwick@u.washington.edu
3740 \pm 100 BP (Brown 1987:27). Other specimens at this site include five backed artefacts and one adze all deposited after 3700 BP (Brown 1987:29). Backed artefacts first appear at Marillana A at 3000 BP and at 1700-1100 BP at Cleft Rock Shelter (Marwick 2002). A single backed geometric microlith occurs at Site P5313 immediately below a 2400 BP date (Brown 1987:43). At RR3-O there are two adzes representing the new Holocene types in association with a $310 \pm 50 \mathrm{BP}$ (Wk 8364) date, suggesting that the new types were continuously present in the Hamersley Plateau until the very late Holocene (Harris 2000:17-25; cf. Hiscock and Veth 1991).

Hiscock (1993, 2001) and James and Davidson (1994) have suggested that a coincidence between the appearance of backed artefacts and increases in artefact discard may represent a sample size effect rather than an important cultural change. This is true here with increases in discard rates of cultural material coinciding with the first appearance of backed artefacts at $3000 \mathrm{BP}$ at Marillana A and 1700-1100 BP at Cleft Rock Shelter (Marwick 2002). Table 1 shows that the strength of correlation between numbers of backed artefacts and excavation unit assemblage size is very low at the five Hamersley Plateau sites with backed artefacts. However, the number of backed artefacts is very small and none of the correlations are significant at the $\mathrm{p}\left(\mathrm{H}_{0}\right)=0.05$ level, so sample size effects on the presence of rare items cannot be ruled out.

\section{The dating of rock art}

Like backed artefacts, increases rock art production are often considered to represent important cultural changes. At Skew Valley on the Burrup Peninsula five buried engraved panels were recovered by Lorblanchet (1983) from a stratified midden deposit associated with charcoal dated to $3770 \pm 80$ BP (ANU 1837), 3410 \pm 80 BP (ANU 1839) and $2770 \pm 70$ BP (ANU 1838). Dragovich (2000) attempted direct radiocarbon dating of rock engravings on the Dampier Archipelago using organic components in the varnish overlaying engravings. The five dates obtained were all less than 2800 BP although the varnish that was stratigraphically lowest in the sample was the youngest while the top layers returned older dates (Dragovich 2000). The date of $2800 \mathrm{BP}$ suggests a date after which the engravings were produced, 


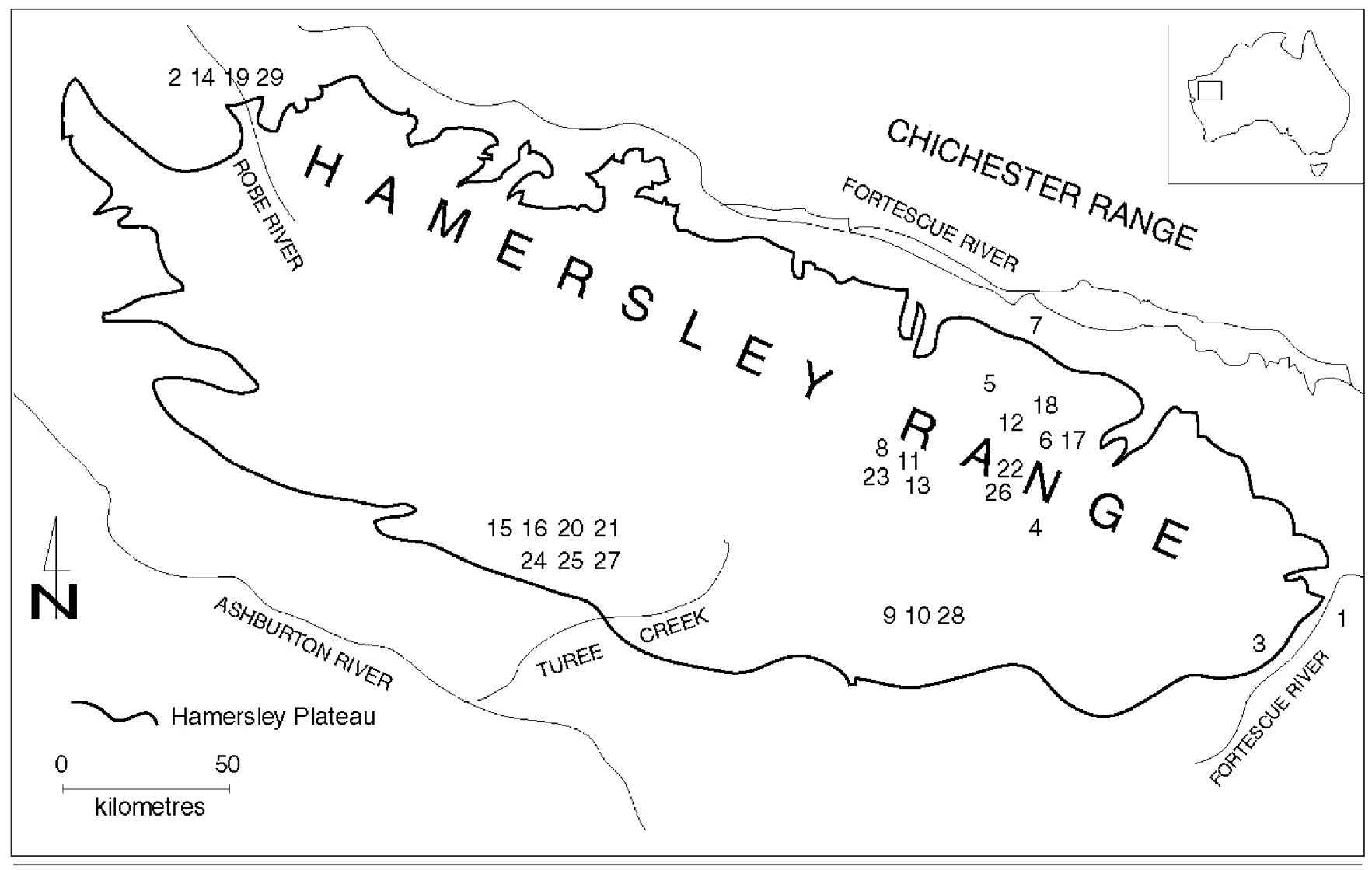

Figure 1. Hamersley Plateau showing sites mentioned in the text.

The numbers indicate the approximate location of sites listed in Table 1.

\begin{tabular}{|c|c|c|c|c|}
\hline Site & $\mathbf{r}$ & $\begin{array}{c}\text { Total } \\
\text { number } \\
\text { of backed } \\
\text { artefacts, etc. }\end{array}$ & $\begin{array}{c}\text { Total } \\
\text { number } \\
\text { of } \\
\text { artefacts }\end{array}$ & Reference \\
\hline $\begin{array}{r}\text { Marillana A } \\
\text { Cleft Rock }\end{array}$ & 0.324 & $2^{\wedge}$ & 1227 & $\begin{array}{c}\text { Marwick } \\
\text { 2002:84-135 }\end{array}$ \\
\hline Shelter & 0.219 & $2^{\wedge}$ & 569 & $\begin{array}{c}\text { Marwick } \\
\text { 2002:151-179 }\end{array}$ \\
\hline Mesa J J23 & 0.229 & $1^{*}$ & 293 & $\begin{array}{c}\text { Hughes and } \\
\text { Quartermaine } \\
\text { 1992:85 }\end{array}$ \\
\hline $\begin{array}{l}\text { Newman } \\
\text { Rockshelter }\end{array}$ & 0.030 & $2^{\wedge}$ & 266 & Brown 1987:27- \\
\hline RR3-O & 0.061 & $2 *$ & 168 & Harris 2000:25 \\
\hline RR3-P & 0.392 & $2^{\wedge}$ & 156 & Harris 2000:26 \\
\hline RR8-P & 0.004 & $1^{*}$ & 152 & Harris 2000:54 \\
\hline P4627 & -0.262 & $1^{\wedge}$ & 63 & Brown 1987:44 \\
\hline P5313 & -0.093 & $1^{*}$ & 30 & Brown 1987:43 \\
\hline \multicolumn{5}{|c|}{$\begin{aligned} \mathrm{r}= & \text { Pearson's product moment correlation coefficient, bold type indicates } \mathrm{p}\left(\mathrm{H}_{0}\right)< \\
& 0.05 \\
* & =\text { adze or geometric microlith } \\
\wedge & =\text { backed artefact }\end{aligned}$} \\
\hline
\end{tabular}

Table 1. Summary of correlations between backed artefacts and stone artefact assemblage size at excavated Hamersley Plateau sites. although ambiguities in the varnish stratigraphy formation and weathering processes limit the validity of these dates. This small and highly ambiguous sample of dates are currently the only absolute dates for rock art in the Hamersley Plateau. These data simply suggest that rock art was produced in the late Holocene and do not permit any conclusions about the first appearance of rock art or increases in its production.

\section{The dating of seed-grinding technology}

Ethnohistoric and ethnographic information from arid and semi-arid Australia suggest that seed-grinding technology may be related to gender-specific subsistence roles, large ritual gatherings and maintenance of social networks (Clarke and Smith 1982:13; Clement 1903:9-11; David 2002:276-8; Withnell 1901: 7-9, 16, 23;). Dates of 17001100 BP for mortar fragments from Cleft Rock Shelter and before 1600 BP from P4507 provide the first evidence of dated grinding stones in the Hamersley Plateau, which are more commonly found in undated surface assemblages (Kee and Quatermaine 1986; Marwick 2002; cf. Veth et al. 2001). These dates for grinding implements at P4507 may not be representative of the true date because of the strong correlation between grinding material and excavation unit 
assemblage size $(r=0.971$, number of grinding pieces $=92$, total number of artefacts in excavated assemblage $=172$, Kee and Quatermaine 1986). The correlation at Cleft Rock Shelter is lower with $r=0.229$ ( $n=4$, total number of artefacts in excavated assemblage $=569$, Marwick 2002). It is noteworthy that the dates of grinding technology are relatively late on the Hamersley Plateau, compared to central Australia where it appears at around 3500 BP (Smith 1986; 1989:99). However, the very small sample of sites with evidence of grinding technology on the Hamersley Plateau limits the confidence that can be placed in any conclusions about the timing and consequences of regionwide technological changes.

\section{The distribution of radiocarbon dates}

Arguments have been made in Australia and internationally for obtaining a general pattern of the timing and intensity of the occupation of sites in a region from analysis of distributions of radiocarbon dates (e.g. Bird and Frankel 1991; David and Lourandos 1999; Gamble et al. 2005; Holdaway et al. 2002; Shennan and Edinborough 2007; Smith and Sharp 1993; Ulm 2006; Ulm and Hall 1996). These arguments are based on the assumption that, all things being equal, as the amount of human activity increases, so does the volume of datable material in the places they inhabit (Rick 1987). However, large numbers of dates are required to convincingly demonstrate patterns. Shennan and Edinborough's (2007) sample of 2311 dates is a typical example. Australian samples generally have much fewer dates, for example Ulm (2006) uses 96 and Lourandos and David (1999) use 165. The late Holocene components of both of these datasets show dramatic increases in the last 1000 years and are interpreted to indicate major reordering of land-use patterns. These authors argue that that a deliberate search for very old sites has biased their date samples in favour of older deposits, cancelling out or at least diminishing preservation biases that favour the representation of younger dates in the sample (Lourandos and David 1999; Ulm 2006). Archaeologists seeking dates from Hamersley Plateau excavations have little choice in selecting datable material; the small quantities of datable material constrain sampling significantly (Harris 2000:18; Hook et al. 2000:94; Hughes and Quartermaine 1992:77; Veitch and Di Lello 2000:40). This suggests that there is no argument for a bias countervailing against preservation.

Following Surovell and Brantingham (2007), a simple model can be employed to investigate the influence of preservation, especially natural decay of organic materials, on the Hamersley Plateau radiocarbon date distributions. If we assume that human behaviours relating to discard of datable remains constant over time, then the change in the amount of the datable materials over time can be described by the equation

$$
n=K e^{-\lambda t}+c
$$

where $n$ indicates the amount of datable material, $K$ is the amount at the time the material is first exposed to taphonomic processes, $\lambda$ is a decay constant, $t$ is the period of time that taphonomic processes have been operating on the material and $c$ represents other functions operating on the amount of datable material (such as demographic changes, changes in site use, etc.). This generic model of exponential decay is chosen because it accurately represents change in quantities over time for many physical phenomena (Leike 2002). By taking logarithms of the exponential decay pattern the behaviour of the data can be easily explored with linear models. The goodness of fit between this equation and the actual distribution of dates will then indicate the importance of preservation bias in shaping the distribution of radiocarbon dates.

In Figure 2 the 65 dates from Table 2 are plotted with arbitrary 500-year sliding intervals measured every 150 years. The 150-year interval approximates the average standard error of 148 years for the sub-sample of oldest or basal dates and 125 years for the total sample (cf. Rick 1987:61). The sliding interval smooths out short-term variations while preserving trends in the raw data but does not account for variations in the standard errors of individual samples. The shape of the distribution of dates resembles the generic model of taphonomic decay in Figure 3. To evaluate the goodness of fit of the model of taphonomic decay, the radiocarbon dates are grouped into 19 bins to remove the rank-order effect. A linear regression is then calculated with the logs of the midpoints of the radiocarbon age intervals of the bins as the dependant variable and the number of dates in each bin as the independent variable. The distribution of the $\log$ (midpoint

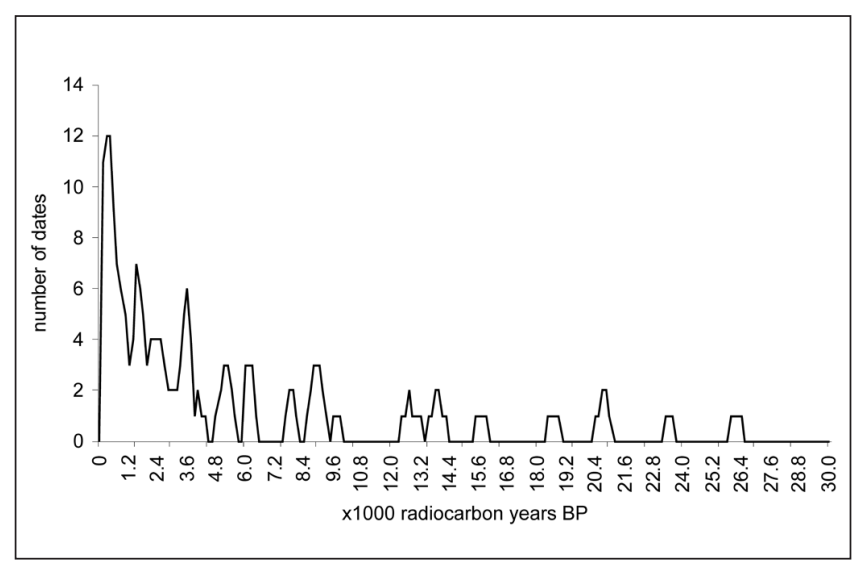

Figure 2. Chronological distribution of all radiocarbon dates $(n=65)$ available from archaeological rockshelter sites in the Hamersley Plateau.

bin interval) data is nearly linear and can be described by the function (Figure 4)

$$
\begin{aligned}
\log (\text { midpoint bin interval })= & -0.137 \text { (number of dates) } \\
& +4.217
\end{aligned}
$$

This function describes $78.5 \%$ of the variation in the sample $\left(F=62.01, \mathrm{p}\left(\mathrm{H}_{0}\right)<0.000\right)$. The small sample of dates and the complex nature of radiocarbon age estimation means that it is difficult to be sure that the assumptions of linear regression have not been violated (independence of 


\begin{tabular}{|c|c|c|c|c|c|c|c|}
\hline $\begin{array}{l}\text { Map } \\
\text { key }\end{array}$ & Site & $\begin{array}{l}\text { Basal or } \\
\text { oldest date }\end{array}$ & & & ther dates & & Ref. \\
\hline \multirow[t]{3}{*}{1} & Newman Rockshelter & $26,300 \pm 500$ & $6,270 \pm 210$ & $3,740 \pm 100$ & & & 1 \\
\hline & & $13,852 \pm 72$ & $9,004 \pm 51$ & $8,862 \pm 51$ & $5,109 \pm 43$ & $6,254 \pm 43$ & 13 \\
\hline & & $3,487 \pm 40$ & $1,388 \pm 37$ & & & & 13 \\
\hline 2 & Mesa J J24 & $23,500 \pm 350$ & $3,950 \pm 110$ & $1,400 \pm 60$ & & & 2 \\
\hline 3 & Newman Orebody XXIX & $20,740 \pm 345$ & $9,870 \pm 80$ & $5,260 \pm 110$ & $3,010 \pm 85$ & & 1 \\
\hline 4 & Malea Rockshelter & $20,950 \pm 330$ & $15,670 \pm 240$ & $2,900 \pm 90$ & $300 \pm 50$ & & 3 \\
\hline 5 & Milly's Cave & $18,750 \pm 460$ & $14,150 \pm 320$ & $719 \pm 57$ & & & 12 \\
\hline 6 & Marillana A & $13,100 \pm 89$ & $9,200 \pm 200$ & $3,630 \pm 70$ & & & 12 \\
\hline 7 & Cleft Rock Shelter & $12,730 \pm 271$ & $7,900 \pm 70$ & $3,610 \pm 70$ & $1,700 \pm 100$ & $1,120 \pm 70$ & 12 \\
\hline 8 & P5315 & $8,090 \pm 80$ & $2,440 \pm 60$ & & & & 1 \\
\hline 9 & RR8 & $4,290 \pm 60$ & $850 \pm 50$ & & & & 4 \\
\hline 9 & P0959 & $6,311 \pm 47$ & $5,425 \pm 45$ & & & & 13 \\
\hline 10 & RR8P & $3,520 \pm 60$ & & & & & 4 \\
\hline 11 & P4627 & $2,640 \pm 130$ & $260 \pm 60$ & & & & 1 \\
\hline 12 & Whaleback & 2,490 & & & & & 5 \\
\hline 13 & P5316 & $2,330 \pm 50$ & & & & & 1 \\
\hline 14 & Mesa J J23 & $2,230 \pm 160$ & $650 \pm 190$ & $240 \pm 80$ & & & 2 \\
\hline 15 & ERP04 & $2,000 \pm 50$ & & & & & 6 \\
\hline 16 & ERP26 & $1,840 \pm 50$ & & & & & 6 \\
\hline 17 & Marillana B & $1,791 \pm 80$ & & & & & 12 \\
\hline 18 & Wallaby Rock Shelter & $1,730 \pm 110$ & & & & & 7 \\
\hline 19 & $\mathrm{P} 4507$ & $1,600 \pm 300$ & & & & & 8 \\
\hline 20 & CME-A-18 & $1,000 \pm 60$ & $390 \pm 50$ & & & & 9 \\
\hline 21 & ERP15 & $950 \pm 50$ & & & & & 6 \\
\hline 22 & P07794(1) & $810 \pm 80$ & & & & & 10 \\
\hline 23 & $\mathrm{P} 4623$ & $770 \pm 50$ & $130 \pm 50$ & & & & 1 \\
\hline 24 & ERP22 & $560 \pm 50$ & & & & & 6 \\
\hline 25 & BM99-10 & $540 \pm 50$ & $470 \pm 50$ & & & & 11 \\
\hline 26 & P07794(2)) & $380 \pm 80$ & & & & & 10 \\
\hline 27 & ERP11b & $370 \pm 50$ & $350 \pm 50$ & & & & 6 \\
\hline 28 & RR3-O & $310 \pm 50$ & & & & & 4 \\
\hline 29 & P4506 & $120 \pm 150$ & & & & & 2 \\
\hline
\end{tabular}

References: 1. Brown 1987; 2. Hughes and Quartermaine 1992; 3. McDonald Hales and Associates 1997, Edwards and Murphy 2003 ; 4. Harris 2000; 5. Strawbridge pers. comm.; 6. Hook et al. 1998; 7. Strawbridge 1992; 8. Kee and Quartermaine 1986; 9. Veitch pers. comm.; 10. Hook et al. 2000; 11. Veitch and Di Lello 2000; 12. Marwick 2002; 13. Comtesse 2003.

Table 2. Radiocarbon dates from archaeological sites used for Figure 2. Inversions and dubious archaeological associations excluded. All dates are uncalibrated conventional radiocarbon ages with one standard deviation (except for Whaleback Rock Shelter where the data are not available).

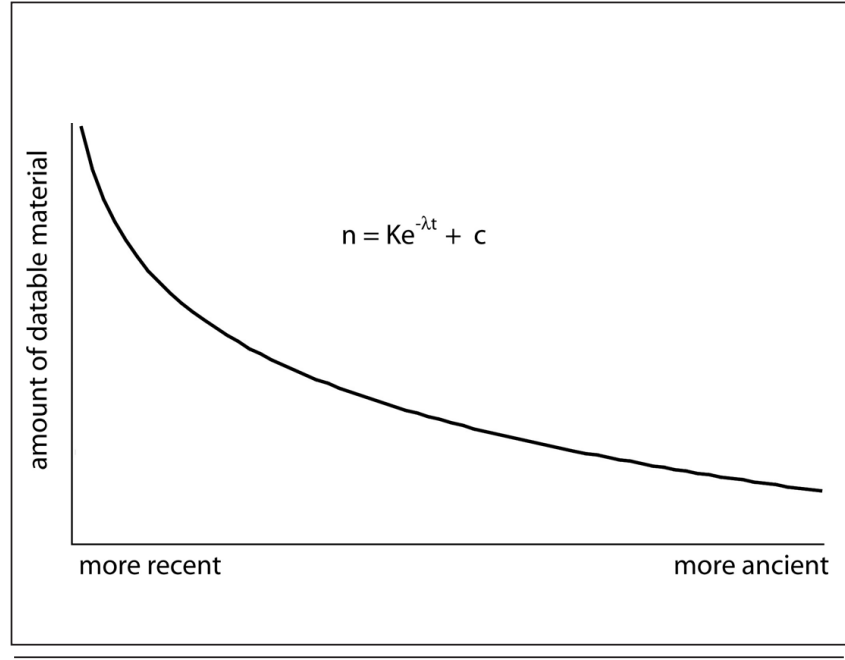

Figure 3. Model of the effect of taphonomic decay on the availability of datable materials in archaeological contexts.

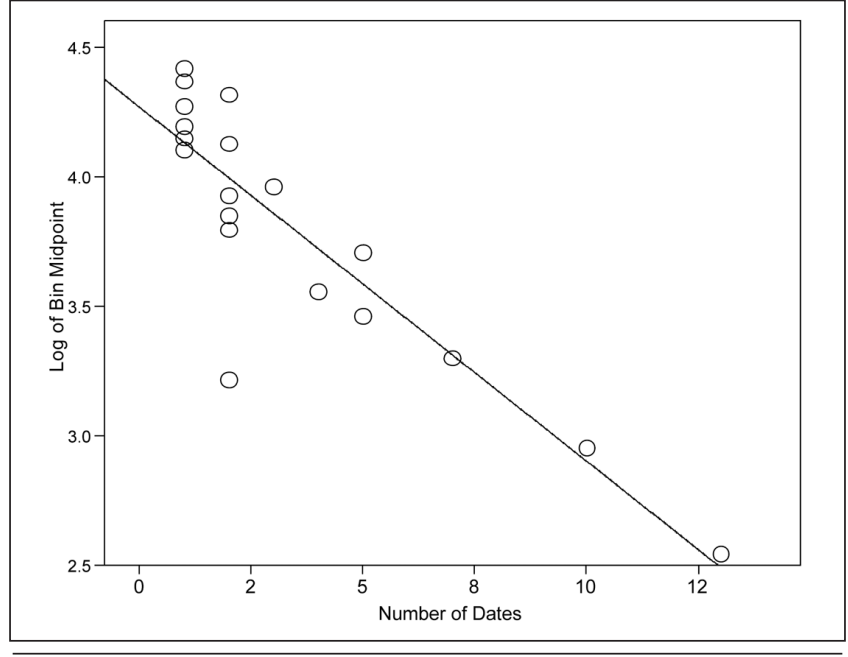

Figure 4. Linear regression fitted to binned radiocarbon dates. 


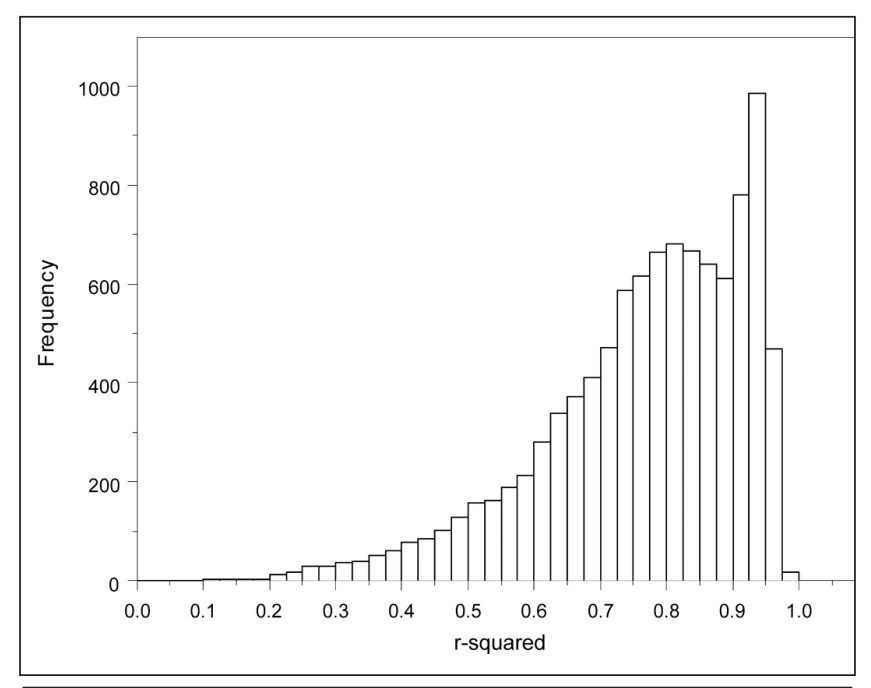

Figure 5. Result of bootstrapping $r^{2}$ regression statistic for cross-validation of the strength of the relationship between the $\log$ (date) sample and their rank order.

values, independence of errors and homogeneity of variance). In a situation like this, cross-validation of the regression model can be undertaking by bootstrapping the $r^{2}$ regression statistic (Chernick 1999; Efron and Tibshirani 1993). Resampling from the original sample of radiocarbon dates 10,000 times gives a 90\% bootstrap confidence interval of $0.462-0.949$ for the $r^{2}$ regression statistic and a mean of 0.766 , supporting the accuracy of the initial value (Figure 5). These results suggest that a model of taphonomic decay is appropriate and that this model explains more than three-quarters of the variation observed in the distribution of radiocarbon dates from the Hamersley Plateau.

Although relatively little variation in the radiocarbon date distribution remains unexplained by taphonomic bias, a general linear model was employed to further assess the role of factors other than taphonomic decay (i.e. the functions represented by $c$ above) operating on the amount of datable material. This model tests the hypothesis that peaks in the distribution of dates reflect culturally significant changes such as demographic expansions or changes in settlement patterns that were related to the first archaeological appearance of backed artefacts, rock art and grinding technology on the Hamersley Plateau. Similar arguments have been made elsewhere in Australia for late Holocene correlations between settlement patterns and social and technological change (e.g. David and Lourandos 1999). For this model, a categorical factor was introduced corresponding to the bin intervals closest to the dates when rock art, backed artefacts and grinding technology first appeared on the Hamersley Plateau. A negative binomial model was found to be the best fit and the model showed no significant effects of the cultural (i.e. non-taphonomic) variable on the distribution of radiocarbon dates $\left(\mathrm{t}=-0.66, \mathrm{p}\left(\mathrm{H}_{0}\right)=0.508\right)$. The implication here is that the distribution of radiocarbon dates from archaeological sites in the Hamersley Plateau does not reveal culturally significant archaeological changes.

\section{Discussion}

The data presented here for the Hamersley Plateau are currently too weak to convincingly engage with relevant themes from neighbouring regions. These themes include the effect of increased climate variability, more open vegetation and decreased rainfall after about $3500 \mathrm{BP}$ (Schulmeister and Lees 1995), links between rock art and the manifestation of group identities (Davidson 1997) and territorial structures similar to ethnographically observed socio-linguistic units (Taçon 1993), the possible adoption of Western Desert section systems, especially after 1600 BP according to linguistic methods (McConvell 1985, 1996, 1997), the westward spread of circumcision rituals (Dench 2001; Gibbs and Veth 2003) and the likelihood that the timing and character of archaeological changes on the Hamersley Plateau cultural are similar to changes throughout the Australian arid zone (Smith 1988; Veth 1993). Only after considerably more data are available can these problems be meaningfully addressed.

The analysis of radiocarbon dates presented here has implications beyond the Hamersley Plateau. Many regions in Australia have similarly shaped distributions of radiocarbon dates from relatively small $(\mathrm{n}<1000)$ samples. In the case of the Hamersley Plateau the shape of the distribution is best explained by taphonomic bias that removes datable material from the archaeological record according to a simple exponential function. This taphonomic effect on radiocarbon date distributions has been observed in a wide variety of archaeological and nonarchaeological contexts (Surovell and Brantingham 2007). Given this generality of taphonomic bias in radiocarbon date distributions it is likely that it is an important but neglected variable in considerations of distributions of archaeological radiocarbon dates throughout Australia, especially in the late Holocene when the effect is pronounced. The informal and suggestive nature of many interpretations of radiocarbon date distributions in Australian archaeology mean that taphonomic bias cannot be eliminated and demographic conclusions remain unconvincing. It is certainly possible that monotonic increases in radiocarbon dates do correspond with exponential increases in human activity and population rather than taphonomic bias, but this relationship needs to be demonstrated using multiple proxies from many sites; a burden of proof that few regions can satisfy (cf. Dortch and Smith 2001). The need for more rigorous and formal treatment of radiocarbon date distributions echoes Hiscock and Faulkner's (2006) recent concern about uncritical invocations of Aboriginal ethnography to infer mechanisms of archaeological change.

\section{Conclusion}

This description of the available data on the dating of new lithic technologies, rock art and possible demographic or settlement system changes has been necessarily limited. The data are few and do not support grand conclusions about regional changes in technology and culture. The timing of 
the first appearances of backed artefacts, rock art and grinding technology are in general agreement with continental trends, but in this specific case the timing of their appearance is probably most parsimoniously explained by sample size effects. Similarly, the most important factor in the distribution of radiocarbon dates appears to be taphonomic bias. Rather than being indecisive, these conclusions reflect the limits of inference and data. These limitations are also likely to apply to late Holocene archaeological data from other regions of Australia.

Nearly all current work on Hamersley Plateau archaeology is conducted by consultant archaeologists and in recent years, with the increased international demand for iron ore, the intensity of archaeological activity has considerably increased. However, the majority of consultant archaeological projects involve only survey and recording of surface sites that provide little relevant additional information to important questions relating to change over time (Marwick 2004). Although recording surface features might be adequate for the requirements of the relevant legislation, more substantial scientific contributions are likely if the priorities and policies of cultural resource management on the Hamersley Plateau are broadened to include chronological questions. Doing so is likely to result in the increased accumulation of archaeological data and opportunities to robustly test the suitability of regional themes as explanations of archaeological record.

\section{Acknowledgements}

This paper derives (and substantially departs) from my MA thesis which was submitted to the University of Western Australia in 2002 and was written while I was at the Australian National University in Canberra. I acknowledge Lynda Strawbridge for her co-operation with my analysis of the material she excavated and BHP for contributing funds to Lynda's work. The University of Western Australia Centre for Archaeology contributed funds towards my analysis of material excavated by Lynda. Thanks to the Innawonga Bunjima Niapiali and Martu Idja Bunyjima people for their co-operation with my MA project. This paper would have been impossible without the co-operation of consultants working in the Hamersley Plateau who provided me with access to their data, especially Gavin Jackson, Fiona Hook and the late Bruce Veitch. Thanks to Jane Balme, Ben Jeffares, Peter Hiscock, Matthew Johnson, Alex Mackay, Kate Morse, Sue O'Connor, Ian Ryan, Peter White and Peter Veth for their comments on previous versions of this paper. Emlyn Williams of the ANU Statistical Consulting Unit provided extensive advice about dealing with the radiocarbon date distribution. Thanks to Kate Morse for encouraging the submission of this paper for publication. Errors of any kind are exclusively mine.

\section{References}

Bird, C.F. and D. Frankel 1991 Chronology and explanation in western Victoria and south-east South Australia. Archaeology in Oceania 26: 1-16.
Bowdler, S. 1981 Hunters in the highlands: Aboriginal adaptation in the eastern Australian uplands. Archaeology in Oceania 16: 99-111.

Bowdler, S. and O'Conner, S. 1991 The dating of the Australian Small Tool Tradition, with new evidence from the Kimberley, WA. Australian Aboriginal Studies 1991/1:53-62.

Brown, S. 1987 Toward a Prehistory of the Hamersley Plateau, Northwest Australia. Occasional Papers in Prehistory 6, Department of Prehistory, Research School of Pacific Studies. Canberra: Australian National University.

Chernick, M.R. 1999. Bootstrap methods: A practitioner's guide. New York: Wiley.

Clarke, C. and M. Smith 1982 Yandicoogina Prospect Western Australia: A survey for Aboriginal sites. Unpublished Report held by Western Australian Department of Indigenous Affairs.

Clement, E. 1903 Ethnographic notes on the Western Australian Aborigines. Internationales Archiv für Ethnographie 16: 1-29.

Comtesse, S. 2003 Mount Newman sites re-analysed. Newman Orebody XXIXZ, Newman rockshelter and P0959. Unpublished BSc (Hons) Thesis, Centre for Archaeology, University of Western Australia.

David, B. 2002 Landscapes, Rock-art and the Dreaming: an Archaeology Preunderstanding. London: Leicester University Press.

David, B. and D. Chant 1995 Rock art and regionalisation in north Queensland prehistory. Memoirs of the Queensland Museum 37: 357-528.

David, B. and H. Lourandos 1999 Landscape as mind: Land use, cultural space and change in north Queensland prehistory. Quaternary International 59: 107-123.

Davidson, I. 1997 The power of pictures. In Conkey, O. Soffer, D. Stratmann and N. Jablonski (eds) Beyond Art: Pleistocene Image and Symbol. pp. 125-58. San Francisco: Memoirs of the California Academy of Sciences 23.

Dench, A. 2001 Descent and Diffusion: The Complexity of the Pilbara Situation. In A.Y. Aikhenvald and R.M.W. Dixon (eds) Areal Diffusion and Genetic Inheritance: Problems in Comparative Linguistics. pp. 105-132. Oxford: Oxford University Press.

Dortch, C. and M. Smith 2001 Grand hypotheses: palaeodemographic modelling in Western Australia's south-west. Archaeology in Oceania 36: 34-45.

Dragovich, D. 2000 Rock engraving chronologies and Accelerator Mass Spectrometry radiocarbon age of desert varnish. Journal of Archaeological Science 27: 871-6.

Edwards, K. and A. Murphy 2003 A preliminary report on Archaeological investigations at Malea Rockshelter, Pilbara region, Western Australia. Australian Archaeology 56: 44-46.

Efron, B. and R.J. Tibshirani. 1993 An introduction to the bootstrap. New York: Chapman \& Hall.

Flood, J., B. David, J. Magee and B. English 1987 Birrigai: A Pleistocene site in the south-eastern highlands. Archaeology in Oceania 22: 9-26.

Gamble, C., Davies, W., Pettitt, P., Hazelwood, L., Richards, M., 2005 The Archaeological and Genetic Foundations of the European Population during the Late Glacial: implications for 'Agricultural Thinking'. Cambridge Archaeological Journal 15: 193-223.

Gibbs, M. and Veth, P. 2003 Ritual engines and territorial ascendancy. Tempus 7: 11-20.

Harris, J. 2000 Interim summary report of archaeological salvage of Mining Area A, West Angelas South. Unpublished Report held by Western Australian Department of Indigenous Affairs HSR 2000 HAR, AC 0371/00.

Hiscock, P. 1993 Interpreting the vertical distribution of stone points within Nauwalabila 1, Arnhem Land. The Beagle. Records of the Northern Territory Museum of Arts and Sciences 10: 173-178.

Hiscock, P. 2001 Sizing up prehistory: Sample size and composition of artefact assemblages. Australian Aboriginal Studies 2001/1: 48-62.

Hiscock, P. 2002 Pattern and context in the Holocene proliferation of backed artefacts in Australia. In Elston, R.G. and Kuhn, S.L. (eds) Thinking Small: Global Perspectives on Microlithization. Archaeological Papers of the American Anthropological Association (AP3A) No. 12, pp.163-177. 
Hiscock, P. and V. Attenbrow 1998 Early Holocene Backed Artefacts from Australia. Archaeology in Oceania 33:49-63.

Hiscock, P. and V. Attenbrow 2004 A revised sequence of backed artefact production at Capertee 3. Archaeology in Oceania 39: 94-99.

Hiscock, P. and P. Faulkner 2006. Dating the Dreaming? Creation of Myths and Rituals for Mounds along the Northern Australian Coastline. Cambridge Archaeological Journal 16: 209-222.

Hiscock, P. and P. Veth (1991) 'Change in the Australian desert culture: a reanalysis of tulas from Puntutjarpa rockshelter', World Archaeology. 22: 332-45.

Holdaway, S., Fanning, P.C., Jones, M., Shiner, J., Witter, D.C. and G. Nicholls 2002 Variability in the chronology of late Holocene Aboriginal occupation on the arid margin of southeastern Australia, Journal of Archaeological Science 29: 351-363.

Hook, F., Jackson, G., Martin, C. and B. Veitch 1998 The report of the test excavation of 11 Aboriginal archaeological sites in the Eastern Ranges project area, Paraburdoo, Pilbara, Western Australia. Unpublished Report held by Western Australian Department of Indigenous Affairs.

Hook, F., Veitch, B. and C. Martin 2000 A report of an Aboriginal archaeological salvage program of sites located on the HI Yandi railway route and mine area, Hamersley Plateau, Western Australia. 2 Vols. Unpublished Report held by Western Australian Department of Indigenous Affairs.

Hughes, P.J and G. Quartermaine 1992 Investigations of Aboriginal archaeological sites in the Mesa J development area, Pannawonica. Unpublished Report held by Western Australian Department of Indigenous Affairs.

James, R. and I. Davidson 1994 Sampling in Australian sites: A Selwyn case study. In I. Johnson (ed.) Methods in the Mountains, pp. 13-9. Sydney: Sydney University Archaeological Methods Series 2.

Kee, S. and G. Quartermaine 1986 Report of further archaeological investigations at the eastern Deepdale development, Pannawonica. Unpublished Report held by Western Australian Department of Indigenous Affairs.

Layton, R. 1996 Small tools and social change. In P. McConvell and N. Evans (eds) Archaeology and Linguistics. Aboriginal Australia in Global Perspective, pp. 377-384. Melbourne: Oxford University Press.

Leike, A. 2002 Demonstration of the exponential decay law using beer froth. European Journal of Physics 23: 21-26

Lourandos, H. 1983 Intensification. A late Pleistocene-Holocene archaeological sequence from southwestern Victoria. Archaeology in Oceania 18: 81-94.

Lourandos, H. and B. David, 1999 Landscape as mind: land use, cultural space and change in north Queensland prehistory. Quaternary International 59: 107-123

Lorblanchet, M. 1983 Chronology of the rock engravings at Gum Tree Valley and Skew Valley near Dampier, Western Australia. In M. Smith (ed) Archaeology at ANZAAS 1983, pp. 180-184. Perth: Western Australian Museum.

Marwick, B. 2002 Hamersley Plateau Archaeology: A study of variation in Aboriginal occupation over time and space on the Hamersley Plateau, Western Australia', MA dissertation, Centre for Archaeology, University of Western Australia.

Marwick, B. 2004 Future Directions for Research into Open Sites and Rockshelters in the Hamersley Plateau. Australian Association of Consulting Archaeologists Incorporated Newsletter, 95: 14-18.

McConvell, P. 1985 The origin of subsections in northern Australia. Oceania 56: 1-33.

McConvell, P. 1996 Backtracking to Babel: The chronology of Pama-
Nyungan expansion in Australia. Archaeology in Oceania 31: $125-44$.

McConvell, P. 1997 Long lost relations: Pama-Nyungan and northern kinship. In P. McConvell and N. Evans (eds) Archaeology and Linguistics. Aboriginal Australia in Global Perspective. pp. 207235. Melbourne: Oxford University Press.

McDonald, Hales and Associates 1997 Hope Downs Aboriginal Heritage Investigations. Western Australian Department of Indigenous Affairs Unpublished Report MCD 1997, 109/97, Perth.

Morwood, M. 1987 The archaeology of social complexity in south-east Queensland. Proceedings of the Prehistoric Society 53: 337-50.

Rick, J.W. 1987 Dates as data: An examination of the Peruvian preceramic radiocarbon record. American Antiquity 52: 55-73.

Schulmeister, J. and Lees, B.G. 1995 Pollen evidence from tropical Australian for the onset of ENSO-dominated climate at c. 4000 BP. The Holocene 5: 10-18.

Shennan, S. and K. Edinborough 2007 Prehistoric population history: From the Late Glacial to the Late Neolithic in Central and Northern Europe. Journal of Archaeological Science 35: 1339-1345

Smith, M. 1986 The antiquity of seed grinding in arid Australia. Archaeology in Oceania. 21: 29-39.

Smith, M. 1988 The Pattern and Timing of Prehistoric Settlement in Central Australia. PhD dissertation, Department of Archaeology and Palaeoanthropology, University of New England.

Smith, M. 1989. The Case for a Resident Human Population in the Central Australian Ranges during Full Glacial Aridity. Archaeology in Oceania 24: 93-105.

Smith, M. and N. Sharp 1993 Pleistocene sites in Australia, New Guinea and island Melanesia: Geographic and temporal structure of the archaeological record. In M.A. Smith, M. Spriggs and B. Fankhauser (eds) Sahul in Review. Pleistocene Archaeology in Australia, New Guinea and Island Melanesia. pp. 37-59. Department of Prehistory, Research School of Pacific Studies, Canberra: Australian National University.

Strawbridge, L. 1992 Survey and detailed recording activities in the Yandi project area, Yandicoogina, Pilbara, Western Australia. Unpublished Report held by Western Australian Department of Indigenous Affairs.

Surovell, T.A. and P.J. Brantingham. 2007. A note on the use of temporal frequency distributions in studies of prehistoric demography. Journal of Archaeological Science doi:10.1016/j. jas.2007.01.003

Taçon, P.S. 1993 Regionalism in the recent rock art of western Arnhem Land, Northern Territory. Archaeology in Oceania 28: 112-120.

Ulm, S. 2006 Coastal Themes: An archaeology of the Southern Curtis Coast, Queensland. Terra Australis 24. Canberra: ANU E Press

Ulm, S. and J. Hall 1995 Radiocarbon and cultural chronologies in southeast Queensland. Tempus 6: 45-62.

Veitch, B. and A. Di Lello 2000 The report of the test excavation of five aboriginal archaeological sites in the proposed pit 4 and 6 extension area situated within the Brockman Mine, Pilbara, Western Australia. Unpublished report held by Hamersley Iron Pty Ltd.

Veth, P. 1993 Islands of the Interior. The Dynamics of Prehistoric Adaptations within the Arid Zone of Australia. International Monographs in Prehistory, Archaeological Series 3, Ann Arbor: International Monographs in Prehistory.

Veth, P., Smith, M. and M. Haley 2001 Kaalpi: the archaeology of an outlying range in the dunefields of the Western Desert. Australian Archaeology 52: 9-17.

Withnell, J.G. 1901 Customs and Traditions of Aboriginal Natives of North Western Australia. Roebourne: Privately published. 